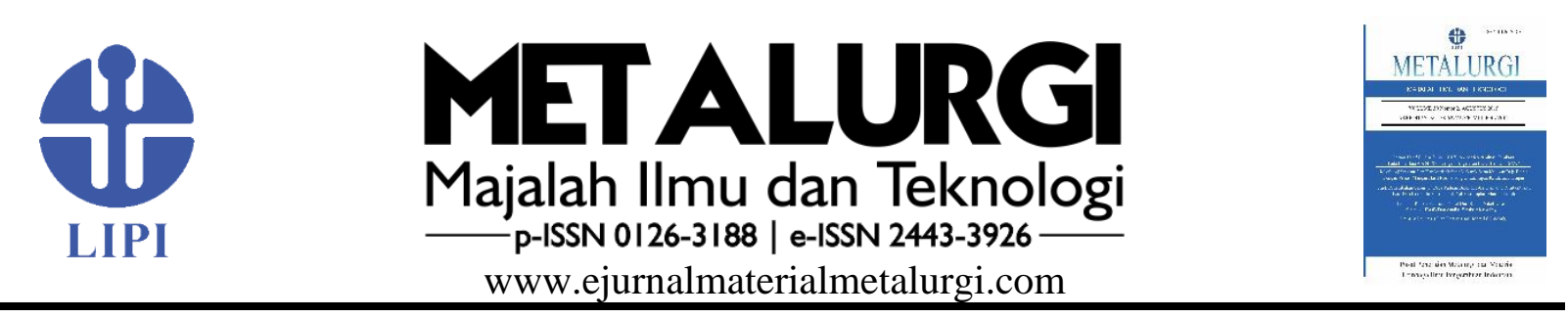

\title{
SYNTHESIS AND CHARACTERIZATION OF NICKEL HYDROXIDE FROM EXTRACTION SOLUTION OF SPENT CATALYST
}

\author{
Kevin Cleary Wanta ${ }^{a, *}$, Felisha Hapsari Tanujaya ${ }^{a}$, Federick Dwi Putra ${ }^{a}$, Ratna Frida \\ Susantia $^{a}$, Gelar Panji Gemilar ${ }^{b}$, Widi Astutic, Himawan Tri Bayu Murti Petrus ${ }^{d}$ \\ ${ }^{a}$ Department of Chemical Engineering, Faculty of Industrial Technology, Parahyangan Catholic University \\ Jalan Ciumbuleuit No. 94 Bandung, Indonesia 40141 \\ bPT Petrokimia Gresik \\ Jalan Jenderal Ahmad Yani, Gresik, Indonesia 61119 \\ ${ }^{\mathrm{c}}$ Research Unit for Mineral Technology, Indonesian Institute of Sciences (LIPI) \\ Jalan Ir. Sutami Km. 15, Tanjung Bintang, Lampung Selatan 35361 \\ ${ }^{\mathrm{d} D e p a r t m e n t}$ of Chemical Engineering, Faculty of Engineering, Universitas Gadjah Mada \\ Jalan Grafika No. 2 Kampus UGM, Yogyakarta, Indonesia 55281 \\ *E-mail: kcwanta@unpar.ac.id
}

Masuk Tanggal :16-11-2020, revisi tanggal:10-12-2020, diterima untuk diterbitkan tanggal : 25-12-2020

\begin{abstract}
Abstrak
Nikel merupakan unsur logam yang esensial dan diaplikasikan dalam berbagai bidang. Salah satu produk turunan berbasis nikel yang bermanfaat adalah nikel hidroksida $\mathrm{Ni}(\mathrm{OH})_{2}$. Senyawa ini banyak diaplikasikan sebagai bahan baku dari elektroda baterai isi ulang, kapasitor, electrolyser, dan katalis. Studi ini berfokus pada sintesis $\mathrm{Ni}(\mathrm{OH})_{2}$ dengan menggunakan metode presipitasi hidroksida. Larutan dari hasil ekstraksi spent catalyst digunakan sebagai larutan prekursor. Setelah larutan prekursor diperoleh, proses presipitasi dilakukan pada $\mathrm{pH} 10$ dimana suhu operasi divariasikan pada $30-60{ }^{\circ} \mathrm{C}$. Larutan $\mathrm{NaOH}, \mathrm{KOH}$, dan $\mathrm{MgO}$ digunakan sebagai agen presipitasi. Hasil eksperimen menunjukkan bahwa senyawa $\mathrm{Ni}(\mathrm{OH})_{2}$ dapat diproduksi secara maksimal pada suhu rendah, $30^{\circ} \mathrm{C}$. Hal ini terindikasi dari nilai konsentrasi ion $\mathrm{Ni}^{2+}$ pada fasa cair terendah yang dicapai pada suhu tersebut. Ketiga agen presipitasi juga memberikan hasil yang baik dalam mempresipitasi ion $\mathrm{Ni}^{2+}$ dimana hampir seluruh ion $\mathrm{Ni}^{2+}$ terpresipitasi dari fasa cair. Produk presipitat yang terbentuk dikarakterisasi dengan menggunakan SEM (scanning electron microscope), XRD ( $x$-ray diffraction), dan XRF ( $x$-ray fluorescence). Hasil analisis menunjukkan bahwa produk teraglomerasi dan tidak berbentuk. Kemurnian presipitat yang terbentuk sebesar 24,1 dan 29\% untuk agen presipitasi $\mathrm{MgO}$ dan $\mathrm{NaOH}$, secara berurutan.
\end{abstract}

Kata Kunci: Nikel hidroksida, presipitasi, spent catalyst, natrium hidroksida, baterai isi ulang

\footnotetext{
Abstract

Nickel is an essential metal element and is applied in various sectors. One of the useful nickel-based derivatives products is nickel hydroxide $\mathrm{Ni}(\mathrm{OH})_{2}$. This compound is widely applied as raw material for electrodes of rechargeable batteries, capacitors, electrolyzers, and catalysts. This study focuses on the synthesis of $\mathrm{Ni}(\mathrm{OH})_{2}$ using the hydroxide precipitation method. A solution from the extraction process of spent catalysts was used as a precursor solution. After the precursor solution was obtained, the precipitation process was carried out at pH 10 , where the operating temperature was varied at 30-60 ${ }^{\circ} \mathrm{C} . \mathrm{NaOH}, \mathrm{KOH}$, and $\mathrm{MgO}$ solutions were used as precipitating agents. The experimental results show that the $\mathrm{Ni}(\mathrm{OH})_{2}$ compounds were produced optimally at low temperatures, $30 \mathrm{oC}$. It could be indicated from the lowest concentration of $\mathrm{Ni2}+$ ions in the liquid phase that reached that temperature. The three precipitation agents also gave good results in the precipitation of Ni2+ions, where almost all of the Ni2+ ions were precipitated from the liquid phase. The precipitated products were characterized using SEM (scanning electron microscope), XRD (x-ray diffraction), and XRF (x-ray fluorescence). The analysis results showed that the product was agglomerated and formless. The purity of the precipitates formed were 24.1 and $29 \%$ for the precipitating agents $\mathrm{MgO}$ and $\mathrm{NaOH}$, respectively.

Keywords: Nickel hydroxide, precipitation, spent catalyst, sodium hydroxide, rechargeable battery
} 


\section{INTRODUCTION}

As in daily life, nickel becomes one of the essential metal elements. Various sectors, such as infrastructure, materials, electronics, plating, transportation, and chemical industries, require nickel as the main and supporting raw materials [1]-[6]. The large and wide utilization of nickel in many sectors is due to its outstanding physical and chemical properties. Some useful nickel characteristics are high melting point, resistance to corrosion and oxidation, highly ductile, alloys readily, magnetic at room temperature, can be deposited by electroplating, to have catalytic properties, and can be recycled entirely [6]-[10].

Nickel can be obtained or recycled by a variety of methods. The conventional and established methods that are usually used involve the smelting method and or the leaching method [11]. The two methods are then followed by the refining or finishing step to obtain a pure nickel product or a nickel derivative product. One of the nickel derivative products that are widely used is nickel hydroxide.

Nickel hydroxide $\mathrm{Ni}(\mathrm{OH})_{2}$ is a nickel derivative compound categorized as an intermediate product. In its utilization, $\mathrm{Ni}(\mathrm{OH})_{2}$ requires further processing so that this compound can be of maximum benefit. The most extensive application of $\mathrm{Ni}(\mathrm{OH})_{2}$ compounds is as active material in the electrode of rechargeable batteries, such as nickel-metal hydride (Ni-MH), nickelhydrogen $\left(\mathrm{Ni}-\mathrm{H}_{2}\right)$, and nickel-cadmium $(\mathrm{Ni}-\mathrm{Cd})$ batteries [12]-[16]. As one of the components of electrode materials for rechargeable batteries, nickel hydroxide can support that battery performance so that the battery has good electrochemical properties; namely, it has high power density, cyclability, and specific energy [17]. The importance of the structure and electrochemical properties of $\mathrm{Ni}(\mathrm{OH})_{2}$ is not limited to applications for manufacturing rechargeable batteries. Several applications such as capacitors, electrolyzers, catalyst also use this nickel compound as raw material [16]-[18].

Nickel hydroxide compounds can be synthesized in various ways, such as through precipitation, electrochemical method, Chimie douce, hydrolysis in polyol medium, and others [19]. Of all these synthesis processes, the hydroxide precipitation process is the most widely used method. This method's advantages are low cost, easy to do, and easy to control [20]. The hydroxide precipitation process principle is to convert the water-soluble ions into the waterinsoluble molecule by adding an alkaline compound as the precipitating agent. The precipitating agents that are usually used in the hydroxide precipitation method are sodium hydroxide $(\mathrm{NaOH})$, magnesium oxide $(\mathrm{MgO})$, calcium oxide $(\mathrm{CaO})$.

The addition of these alkaline compounds will increase the solution's $\mathrm{pH}$, then create conditions in which a metal ion has low solubility in the liquid phase. In general, the chemical reaction that occurs during the hydroxide precipitation process is [21]:

$$
\mathrm{M}^{2+}+2 \mathrm{OH}^{-} \leftrightarrow \mathrm{M}(\mathrm{OH})_{2}
$$

with $\mathrm{M}$ is a metal element. Each metal ion has an optimum $\mathrm{pH}$ to obtain maximum metal hydroxide precipitates. This $\mathrm{pH}$ condition will affect the concentration of dissolved metal ions in solution [20]. If the $\mathrm{pH}$ is above the optimum $\mathrm{pH}$ value, it is possible to form complex soluble compounds. The reaction equation that occurs is as follows [21]:

$$
\mathrm{M}^{2+}+2 \mathrm{OH}^{-} \leftrightarrow \mathrm{M}(\mathrm{OH})^{+}
$$

Apart from the precipitation agents used, another important and main raw material for the precipitation process is the precursor solution. This solution provides the main source of metal ions. The synthesis of $\mathrm{Ni}(\mathrm{OH})_{2}$ has been widely studied using synthetic precursor solutions, such as nickel sulfate $\left(\mathrm{NiSO}_{4}\right)$, nickel chloride $\left(\mathrm{NiCl}_{2}\right)$, or nickel nitrate $\left[\mathrm{Ni}\left(\mathrm{NO}_{3}\right)_{2}\right]$ solution [22]. In this study, the precursor solution used was the solution from the extraction process of spent catalysts. The use of extract solutions as a precursor for the synthesis of $\mathrm{Ni}(\mathrm{OH})_{2}$ has not been widely studied.

The main difference between the two precursor solutions lies in the metal ion content in that solution. In synthetic solutions, the metal ion content is only (or dominated) by $\mathrm{Ni}^{2+}$ ions. However, the types of metal ions contained in the extract solution vary widely. In our other study [23], the extract solution had not only nickel (Ni) elements but also other metal elements, such as aluminum $(\mathrm{Al})$, iron $(\mathrm{Fe})$, sodium $(\mathrm{Na})$. In other words, if the precipitation process is applied in that solution, the formed precipitate products will contain more than one metal element. This condition raises whether the metal ions contained in the precursor solution affect the formation of $\mathrm{Ni}(\mathrm{OH})_{2}$ products, especially regarding the characteristic of the precipitate products, such as the purity, phase minerals, and morphology of precipitates. It is the main focus of this study. This study also studied the effect of temperature and the type of precipitating agent on the $\mathrm{Ni}(\mathrm{OH})_{2}$ synthesis process, especially the effect of a precipitating agent on the precipitates' character. 


\section{Materials AND Method}

\subsection{Materials}

The primary raw material for this study is the spent catalyst from PT. Petrokimia Gresik, East Java Province. These spent catalysts contain several metal elements, which were presented in Table 1. Sulfuric acid solution $\left(\mathrm{H}_{2} \mathrm{SO}_{4}\right)$ was used as a leaching agent in the extraction process of metal ions from the spent catalysts. Also, sodium hydroxide $(\mathrm{NaOH})$, potassium hydroxide $(\mathrm{KOH})$, and magnesium oxide $(\mathrm{MgO})$ were used as precipitating agents.

Table 1 . The composition of spent catalyst

\begin{tabular}{lccccc}
\hline Element & $\mathrm{Al}$ & $\mathrm{Ni}$ & $\mathrm{Si}$ & $\mathrm{Fe}$ & $\mathrm{Cr}$ \\
\hline Composition, \%wt & 16.7 & 6.5 & 0.4 & 0.1 & 0.02 \\
\hline
\end{tabular}

\subsection{Procedure}

There were 3 (three) steps carried out in the $\mathrm{Ni}(\mathrm{OH})_{2}$ synthesis, namely (1) the precursor solution preparation step, (2) the synthesis of $\mathrm{Ni}(\mathrm{OH})_{2}$ step, and (3) $\mathrm{Ni}(\mathrm{OH})_{2}$ characterization. The workflow of this study is presented in Figure 1.

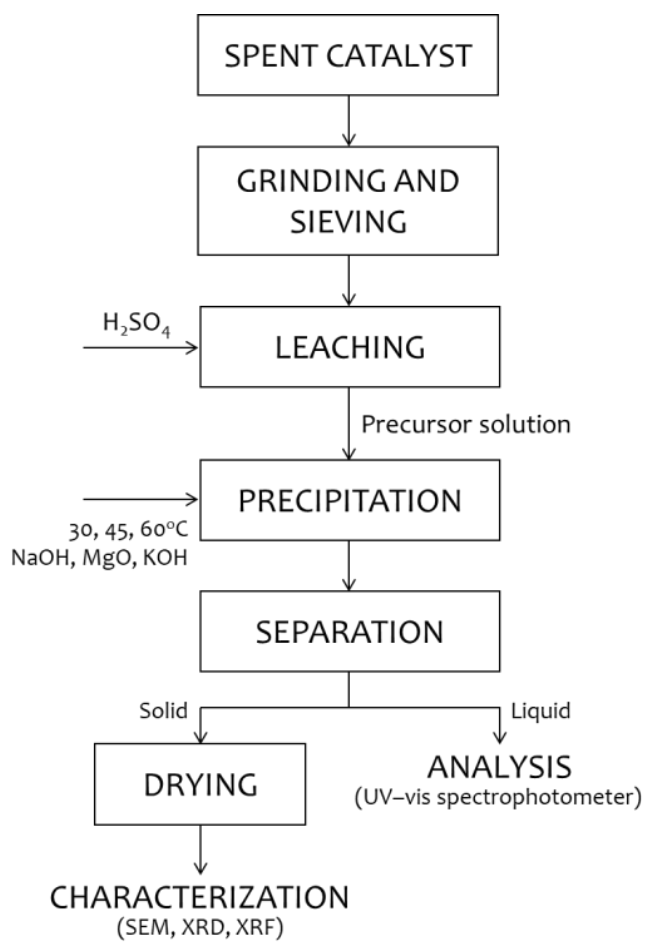

Figure 1. The workflow of $\mathrm{Ni}(\mathrm{OH})_{2}$ synthesis from the extraction solution of spent catalyst

In the first step, precursor solutions were made by extracting metal ions in the spent catalysts, especially $\mathrm{Ni}^{2+}$ ions. The spent catalysts were crushed first until it reaches a size of less than $0.149 \mathrm{~mm}$ so that the extraction process could take place optimally and fast. The extraction process took place in a series of equipment consisting of a glass extractor, condenser, and hot magnetic stirrer. As a leaching agent, sulfuric acid $\left(\mathrm{H}_{2} \mathrm{SO}_{4}\right)$ solution $(5 \mathrm{M})$ was used. The leaching process took place until the equilibrium conditioned was attained, where at this equilibrium condition, the metal ions have been completely dissolved into the solvent. After the solution reached equilibrium, and was analyzed, the precursor solutions contain $514,705 \mathrm{ppm}$ of $\mathrm{Ni}^{2+}$ ions and 235,294 ppm of $\mathrm{Al}^{3+}$ ions.

In the next step, the resulted precursor solution was utilized to synthesize $\mathrm{Ni}(\mathrm{OH})_{2} .50$ $\mathrm{ml}$ of the precursor solution was taken and poured into an Erlenmeyer flask. After that, the concentrated $\mathrm{NaOH}$ solution was dropped into the flask until the solution's $\mathrm{pH}$ reached 10 . This $\mathrm{pH}$ value of 10 was used because, at this condition, the $\mathrm{Ni}^{2+}$ ions precipitation process run optimally [23]. A stirring process also followed the process of dropping the $\mathrm{NaOH}$ solution. The precipitation process run at various temperatures of 30,45 , and $60{ }^{\circ} \mathrm{C}$ while the operating pressure was at atmospheric conditions.

When the solution's $\mathrm{pH}$ reached 10 , the stirring process was stopped. The solution was left for 4 hours. During that time, the precipitation process was carried out according to its mechanism. After 4 hours, the suspension solution formed was separated between the liquid phase and the solid phase. The liquid phase was analyzed for the remaining $\mathrm{Ni}^{2+}$ ions content in that phase. This analysis was performed using UV-vis spectrophotometer. Dimethylglyoxime reagent was also added as a complexing agent during the analysis of the $\mathrm{Ni}^{2+}$ ions [24].

The solid sample formed from the precipitation process was washed and dried until the solid mass did not change anymore. After the solid sample was dry, the sample was characterized by using SEM (scanning electron microscope), XRD (x-ray diffraction), and XRF (x-ray fluorescence). The precipitation step was repeated with the same procedure for the other precipitation agents, namely $\mathrm{KOH}$ and $\mathrm{MgO}$.

\section{Results AND Discussion}

\subsection{The Effect of Temperature on Decreasing} $\mathrm{Ni}^{2+}$ Ions Concentration

Temperature is an essential parameter in the synthesis of $\mathrm{Ni}(\mathrm{OH})_{2}$. This parameter influences the rate of formation of $\mathrm{Ni}(\mathrm{OH})_{2}$ and the solubility of $\mathrm{Ni}(\mathrm{OH})_{2}$. Theoretically, the high temperature causes the kinetic energy of the molecules in the system to be greater so that the rate of precipitation reaction and the formation of $\mathrm{Ni}(\mathrm{OH})_{2}$ will also be faster. However, The 
increase of temperature will also increase the solubility of $\mathrm{Ni}(\mathrm{OH})_{2}$. This condition causes the probability in the precipitates that have been formed dissolving back into the liquid phase will also increase. The experimental results of this study are presented in Figure 2.

Figure 2 shows the effect of temperature on $\mathrm{Ni}^{2+}$ ion concentration in the liquid phase after the synthesis of $\mathrm{Ni}(\mathrm{OH})_{2}$ has been completed. The profile of the results obtained in that figure informs that the higher the temperature used, the final $\mathrm{Ni}^{2+}$ ions concentration in the solution also increases, which indicating the decrease of $\mathrm{Ni}^{2+}$ ions conversions from the liquid phase to the solid phase. As a result, the ability to form $\mathrm{Ni}(\mathrm{OH})_{2}$ compounds will decrease as well.

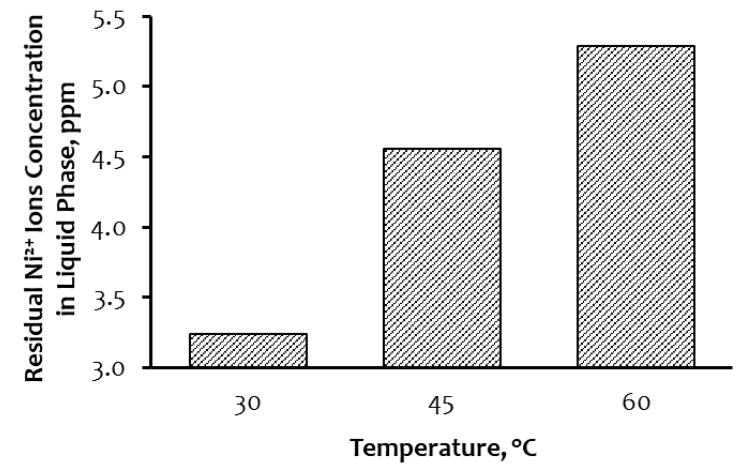

Figure 2. The effect of temperature on decreasing $\mathrm{Ni}^{2+}$ ions concentration in the synthesis of $\mathrm{Ni}(\mathrm{OH})_{2}$

This study experimental comes from experiments designed at $\mathrm{pH} 10$, where this condition is the optimum $\mathrm{pH}$ for precipitating $\mathrm{Ni}^{2+}$ ion [23]. In the use of higher operating temperatures, the conditions obtained in Figure 2 can occur because of an apparent shift in the optimum $\mathrm{pH}$ of the precipitation towards a lower pH. In their study, Albrecht et al. [25] stated that a shift in metal ion stability could occur at higher operating temperatures in the process of hydroxide precipitation. The phenomenon of shifting metal ion's stability was evidenced by the deposition of the metal ion hydroxide at a lower $\mathrm{pH}$.

Albrecht's study results provide a strong suspicion that this study also occurs in this study, especially when the precipitation process was operated at 45 and $60{ }^{\circ} \mathrm{C}$. That condition causes at $\mathrm{pH} 10, \mathrm{Ni}^{2+}$ ions do not precipitate, and $\mathrm{Ni}(\mathrm{OH})_{2}$ precipitates are not formed optimally. The formation of this $\mathrm{Ni}(\mathrm{OH})_{2}$ precipitate product will be optimal at $\mathrm{pH} 10$ when the temperature is set at $30^{\circ} \mathrm{C}$.

The high and low temperature is also related to the solubility of a compound. In this study, the results shown in Figure 2 can occur because, at higher temperatures, $\mathrm{Ni}(\mathrm{OH})_{2}$ compounds' solubility may also increase. Consequently, the concentration of $\mathrm{Ni}^{2+}$ ions in the liquid phase will increase at high temperatures.

The precipitation reaction is reversible because it forms complex compounds and does not dissolve in liquids. In general, this reaction is exothermic. In other words, if this precipitation reaction takes place at a higher temperature, the equilibrium reaction will tend to shift towards the reactants. As a result, the formation of precipitates will be inhibited and in a smaller amount.

The trend obtained during this study is in line with the sturvey conducted by Basturkcu and Acarkan [26]. Studies from Basturkcu and Acarkan prove that in studying the coprecipitation process for other metal ions, namely $\mathrm{Fe}$ from a mixture with nickel, the best conditions are achieved at higher temperatures. The use of temperature impacts reducing the percentage of nickel precipitated (nickel loss) during the Fe coprecipitation process. This study strengthens and proves that the $\mathrm{Ni}^{2+}$ ion precipitation process will run optimally when the temperature is low or at room temperature.

\subsection{The Effect of Precipitating Agent on Decreasing $\mathrm{Ni}^{2+}$ Ions Concentration}

The synthesis of $\mathrm{Ni}(\mathrm{OH})_{2}$ compounds by chemical precipitation method requires a precipitation agent so that the reaction to form the compound occurs. In this study, a type of precipitation agent was studied in which $\mathrm{NaOH}$, $\mathrm{KOH}$, and $\mathrm{MgO}$ were used as precipitation agents. The experimental results of this variation are presented in Figure 3.

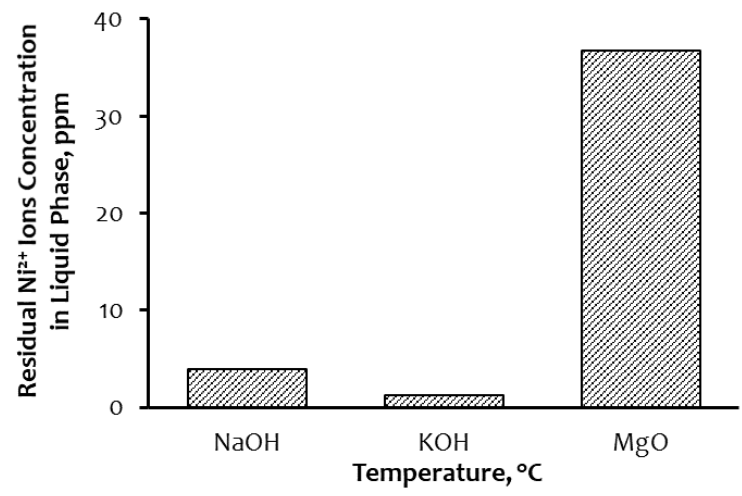

Figure 3. The effect of the precipitating agent on decreasing $\mathrm{Ni}^{2+}$ ions concentration in the synthesis of $\mathrm{Ni}(\mathrm{OH})_{2}$

Figure 3 shows the remaining $\mathrm{Ni}^{2+}$ ions concentration in the liquid phase after the precipitation process takes place. The results showed that $\mathrm{KOH}$ 's use as a precipitating agent gave the smallest concentration of $\mathrm{Ni}^{2+}$ ions, 1.29 
ppm. This result indicates that $\mathrm{KOH}$ is the best precipitating agent in the $\mathrm{Ni}(\mathrm{OH})_{2}$ synthesis process because almost $100 \%$ of $\mathrm{Ni}^{2+}$ ions turn into precipitated products insoluble in the precursor solution. $\mathrm{KOH}$ 's usage is slightly better than $\mathrm{NaOH}$ even though $\mathrm{NaOH}$ is also classified as a right precipitation agent. More than $99 \%$ of the $\mathrm{Ni}^{2+}$ ion concentration is no longer in the liquid phase. $\mathrm{NaOH}$ and $\mathrm{KOH}$ have relatively the same abilities as a precipitating agent because the two compounds have similar characters (classified as alkali metal hidroxides).

Magnesium oxide is also classified as a suitable precipitating agent in $\mathrm{Ni}(\mathrm{OH})_{2}$ synthesis. Based on Figure 3, the use of $\mathrm{MgO}$ gives the highest residual $\mathrm{Ni}^{2+}$ ions concentration compared to $\mathrm{NaOH}$ and $\mathrm{KOH}$, which is 36.76 ppm. $\mathrm{MgO}$ is still categorized as a precipitation agent because more than $98 \%$ of the $\mathrm{Ni}^{2+}$ ions have been removed from the liquid phase and moved to the solid phase (precipitates). Magnesium oxide $(\mathrm{MgO})$ can precipitate large amounts of metal ions. Besides reacting to form $\mathrm{Ni}(\mathrm{OH})_{2}, \mathrm{MgO}$ also can adsorb metal ions [27]. As a result, $\mathrm{Ni}^{2+}$ ions are reduced from the liquid phase and can occur through two mechanisms: losses due to precipitation and losses due to adsorption. This condition causes in the possibility of decreasing the level of selectivity to the precipitation process.

\subsection{Characterization of $\mathrm{Ni}(\mathrm{OH})_{2}$ Precipitates}

The $\mathrm{Ni}(\mathrm{OH})_{2}$ product formed from the precipitation process using the $\mathrm{NaOH}$ precipitation agent at room temperature was characterized using several instruments. This characterization will also be compared with the precipitate products' characterization results using another precipitation agent, $\mathrm{MgO}$. The first analysis was performed using SEM (scanning electron microscope). The purpose of this analysis is to determine the morphology of the precipitates produced. The analysis results are presented in Figure 4, where the magnification used is 3,000x.

The precipitates formed from the precipitation agents $\mathrm{NaOH}$ and $\mathrm{MgO}$ show a similar morphology based on the analysis results, with irregular and formless morphologies. These results have a different morphology from the study conducted by Hall et al. [22]. This condition differs from the precipitation results in previous studies due to differences in the precursor solutions used. In another study, the precursor solution was a synthetic nickel-based solution, while the precursor solution used in this study was an extract solution from spent catalysts.
The extract solution used contains various types of metal ions, such as $\mathrm{Ni}^{2+}$ dan $\mathrm{Al}^{3+}$ ions, in which these metal ions will also be precipitated if they bond to one another. This condition is also proven by the results of precipitates testing using XRD (x-ray diffraction), as shown in Figure 5.

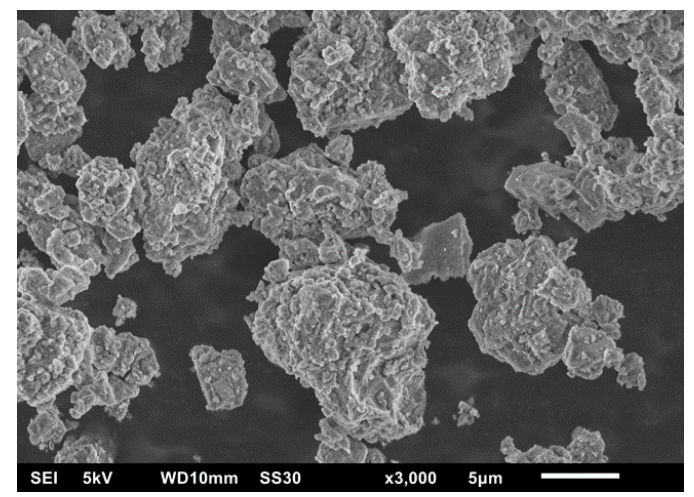

(a)

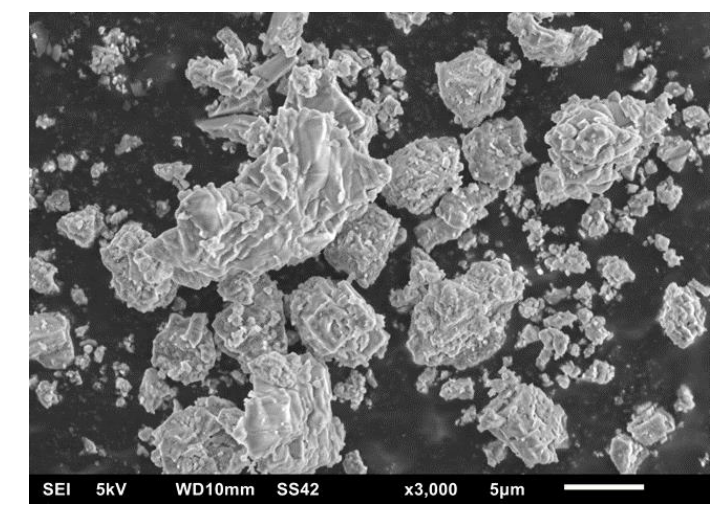

(b)

Figure 4. The morphology of precipitates formed from the precipitation process using: (a) $\mathrm{NaOH}$ and (b) $\mathrm{MgO}$ as precipitating agent

Figure 5 shows that in the two precipitates formed, there are crystalline forms other than $\mathrm{Ni}(\mathrm{OH})_{2}$, such as sodium sulfate $\left(\mathrm{Na}_{2} \mathrm{SO}_{4}\right)$, magnesium sulfate $\left(\mathrm{MgSO}_{4}\right)$, and aluminum hydroxide $\mathrm{Al}(\mathrm{OH})_{3}$. These three compounds are impurities from the precipitate product. Sulfuric salt contaminants are obtained the excess sulfuric acid solution $\left(\mathrm{H}_{2} \mathrm{SO}_{4}\right)$ during the precursor solution's preparation step. The sulfuric acid solution acts as a solvent for metal ions in the spent catalyst. The remaining sulfuric acid molecules that do not react with the metal compounds in the catalyst react with the precipitating agent. For example, $\mathrm{NaOH}$ 's use during the precipitation step causes a side reaction in which the $\mathrm{Na}_{2} \mathrm{SO}_{4}$ compound will also form. The reaction equation that occurs is:

$$
\mathrm{NaOH}+\mathrm{H}_{2} \mathrm{SO}_{4} \rightarrow \mathrm{Na}_{2} \mathrm{SO}_{4}+\mathrm{H}_{2} \mathrm{O}
$$

Also, spent catalysts, as the primary raw material, contain elements of aluminum and other metals. During the extraction process, the aluminum ions 
also dissolve in the precursor solution. Thus, a precipitation agent's addition to the solution also impacts the emergence of another side reaction, namely the formation of the compound $\mathrm{Al}(\mathrm{OH})_{3}$. This compound is also formed in the system because $\mathrm{Al}^{3+}$ ions can be optimally precipitated at $\mathrm{pH} 6$ [20]. The $\mathrm{Ni}(\mathrm{OH})_{2}$ synthesis process is carried out at $\mathrm{pH} 10$ so that in this study, during the process of raising the $\mathrm{pH}$ from low $\mathrm{pH}$ to $\mathrm{pH}$ 10 , the $\mathrm{Al}^{3+}$ ion will also be precipitated.
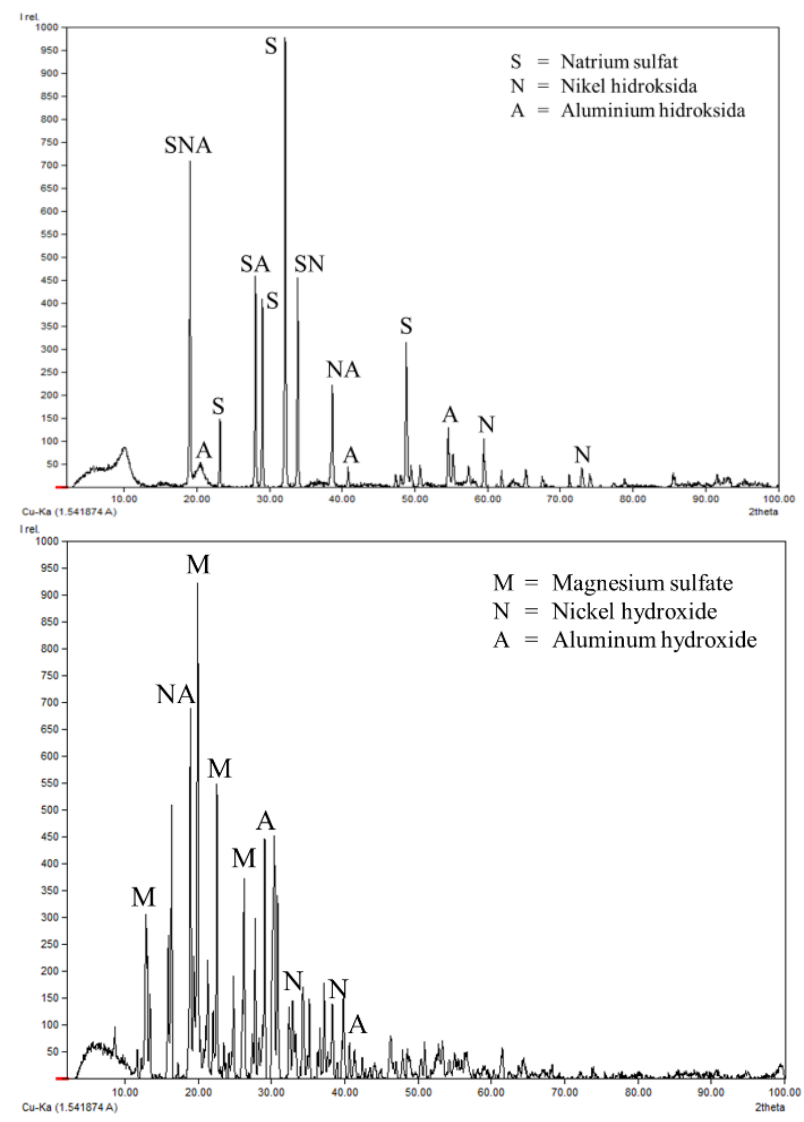

Figure 5. XRD patterns on precipitates formed from the precipitation process using $\mathrm{NaOH}$ (top) and $\mathrm{MgO}$ (bottom) as precipitating agent

Some of these contaminants' emergence causes the precipitates to form as a collection of various molecules that bond and agglomerate each other. The formation of this agglomeration phenomenon also causes the precipitates to have an irregular shapes and produce a relatively large molecular size. Agglomeration takes place when two or more particles come into contact and coalesce over a relatively long period. This agglomeration can be minimized as much as possible, especially if small (nano) size precipitates are to be produced. It is because if large particles are formed, it causes the precipitate's surface area to shrink. This small surface area will minimize optimum performance when applied to various applications.
Excessive precipitation duration can cause the formation of this agglomeration. Precipitation reactions are classified as spontaneous reactions in which as soon as the precipitating agent is added to the precursor solution, the precipitated products will immediately form. In this study, the precipitation time used is four hours, which considers a long enough precipitation time for agglomeration phenomena to be promoted. As a result, the resulting solid products overlap with each other and do not for an independent crystal.

This agglomeration phenomenon usually decreases the resulting precipitates' purity, mainly when the precursor solution consists of many metal ions. This precipitate's purity is also influenced by the mother liquor, which tends to be trapped in the interstitial space between the agglomerate crystals [20]. A similar phenomenon was also found in this study in which precipitate purity is affeted by the presences of impurities in the precursor solution. The precipitate's purity was analyzed using XRF (x-ray fluorescence), and the analysis result is presented in Table 2.

Table 2. The composition of the precipitates formed

\begin{tabular}{ccc}
\hline \multirow{2}{*}{ Element } & \multicolumn{2}{c}{ Composition, wt.\% } \\
\cline { 2 - 3 } & NaOH* & MgO* $^{*}$ \\
\hline $\mathrm{S}$ & 29.2 & 47.3 \\
$\mathrm{Na}$ & 16.5 & - \\
$\mathrm{Mg}$ & - & 11.8 \\
$\mathrm{Ni}$ & 29.0 & 24.1 \\
$\mathrm{Al}$ & 23.2 & 13.2 \\
$\mathrm{Si}$ & 0.3 & 1.4 \\
$\mathrm{~K}$ & 0.1 & 0.2 \\
$\mathrm{Ca}$ & 0.7 & 0.9 \\
$\mathrm{Cr}$ & 0.2 & 0.2 \\
$\mathrm{Fe}$ & 0.8 & 0.7 \\
\hline
\end{tabular}

*as precipitating agent

Based on Table 2, the precipitate formed's purity was $29 \% \mathrm{Ni}$ for the precipitation experiment using $\mathrm{NaOH}$ as the precipitating agent and $24.1 \% \mathrm{Ni}$ for that using $\mathrm{MgO}$ as the precipitating agent. This purity value is classified as low because the $\mathrm{Ni}(\mathrm{OH})_{2}$ must be of high purity, with $\mathrm{Ni}(\mathrm{OH})_{2}$ purity of above $99 \%$. As previously stated, the results of XRF analysis on the precipitates formed further prove the results of other tests that the four largest contaminants are sulfur $(\mathrm{S})$, sodium $(\mathrm{Na})$ or magnesium $(\mathrm{Mg})$, and aluminum (Al). For the two precipitates, about $70 \%$ are the contaminants that should be removed from the precipitate product.

The precipitates produced in this study can be optimized in terms of the quality of the precipitates. The low $\mathrm{Ni}(\mathrm{OH})_{2}$ purity can be increased by removing the contaminants it 
contains. The removal of aluminum elements can be done by applying a multistage precipitation process. Aluminum (III) ions can be converted into precipitation solids at a lower $\mathrm{pH}$, namely at pH 6, while nickel (II) ions will be optimum at $\mathrm{pH}$ 10. Thus, in the case of using precursor solutions such as this study, the precipitation process can be carried out first at $\mathrm{pH} 6$ to remove the aluminum element. The remaining liquid phase is continued by the precipitating process to produce $\mathrm{Ni}(\mathrm{OH})_{2}$ compound. Based on the results of theoretical calculations and the assumption that all $\mathrm{Al}$ elements are precipitated at $\mathrm{pH} 6$, the purity of $\mathrm{Ni}(\mathrm{OH})_{2}$ from this experiment is estimated to increase up to $8.8 \%$.

Apart from that, another effort that can be done is to wash the precipitate product as well gradually. It is done the elements $\mathrm{Na} / \mathrm{Mg}$ and $\mathrm{S}$. Sulfate salts, such as sodium sulfate $\left(\mathrm{Na}_{2} \mathrm{SO}_{4}\right)$ and magnesium sulfate $\left(\mathrm{MgSO}_{4}\right)$, which are classified as watersoluble compounds. Thus, this salt compound can be removed by using repeated washing. To get more optimal results regarding the precipitate's size, the precipitation process can also be done by adding surfactants or using sonication media. It aims to obtain a more regular precipitate and a smaller and more uniform particle size.

\section{Conclusion}

In this work, the synthesis and characterization of nickel hydroxide from the extracted solution of the spent catalyst were studied. This study indicates that the $\mathrm{Ni}(\mathrm{OH})_{2}$ synthesis process runs optimally when the temperature is operated at a low temperature, 30 ${ }^{\circ} \mathrm{C}$. As a precipitation agent, $\mathrm{NaOH}, \mathrm{KOH}$, and $\mathrm{MgO}$ give good results where almost all of the $\mathrm{Ni}^{2+}$ ions are precipitated into $\mathrm{Ni}(\mathrm{OH})_{2}$ compounds. The morphology characterization of the precipitates formed shows that the products are mutually agglomerated between molecules and are formless. Also, $\mathrm{Ni}(\mathrm{OH})_{2}$ was low, where the purity of the precipitate was 24.1 and $29 \%$ for the precipitating agents $\mathrm{MgO}$ and $\mathrm{NaOH}$, respectively. The precipitate's low purity is due to many contaminants, such as $\mathrm{Na}_{2} \mathrm{SO}_{4} / \mathrm{MgSO}_{4}$ and $\mathrm{Al}(\mathrm{OH})_{3}$ in the precipitate product.

\section{ACKNLOWLEDGEMENT}

The authors would like to thank the Institute for Research and Community Service (LPPM), Parahyangan Catholic University, for funding this research (No.: III/LPPM/2020-01/07-P). The authors also thank PT. Petrokimia Gresik has provided spent catalysts as raw materials and LIPI's Science Services for Research Laboratories because of their support as partners in sample analysis.

\section{REFERENCE}

[1] McRae Michele/United Stated Geological Survey, "Nickel Statistic and Information," pp. 2, 2020.

[2] M. Cempel and G. Nikel, "Nickel: A review of its sources and environmental toxicology," Polish J. Environ. Stud., vol. 15, no. 3, pp. 375-382, 2006.

[3] G. Larco, "Nickel, world production and demand nickel, world production and demand," Balk. Min. Congr., pp. 28-34, 2014.

[4] K. C. Wanta, F. H. Tanujaya, R. F. Susanti, H. T. B. M. Petrus, I. Perdana, and W. Astuti, "Studi kinetika proses atmospheric pressure acid leaching bijih laterit limonit menggunakan larutan asam nitrat konsentrasi rendah," J. Rekayasa Proses, vol. 12, no. 2, p. 19, 2018.

[5] A. Nieto, V. Montaruli, and M. Cardu, "The strategic importance of nickel: scenarios and perspectives aimed at global supply," Trans. Soc. Min., Met. Explor, vol. 334, pp. 510-518, 2013.

[6] Nickel Institute, (2016). The life of Ni. Nickel Institute, [Online]. Available: https://nickelinstitute.org/media/1190/thel ifeofni.pdf.

[7] K. C. Wanta, I. Perdana, and H. T. B. M. Petrus, "Evaluation of shrinking core model in leaching process of Pomalaa nickel laterite using citric acid as leachant at atmospheric conditions," IOP Conf. Ser. Mater. Sci. Eng., vol. 162, no. 1, 2016.

[8] F. Bidault, D. J. L. Brett, P. H. Middleton, N. Abson, and N. P. Brandon, "A new application for nickel foam in alkaline fuel cells," Int. J. Hydrogen Energy, vol. 34, no. 16, pp. 6799-6808, 2009.

[9] D. Zhu, X. Zhang, and H. Ding, "Tool wear characteristics in machining of nickel-based superalloys," Int. J. Mach. Tools Manuf., vol. 64, pp. 60-77, 2013.

[10] K. C. Wanta, W. T. Gunawan, R. F. Susanti, G. P. Gemilar, H. T. B. M. Petrus, and W. Astuti, "Subcritical water as a solvent for extraction of nickel and aluminum ions from reforming spent catalysts," IOP Conf. Ser. Mater. Sci. Eng., vol. 742, no. 1, 2020.

[11] J. Kyle, "Nickel laterite processing technologies - where to next?" in ALTA $2010 \mathrm{Nickel} / \mathrm{Cobalt} / \mathrm{Copper}$ Conference, pp. 1-36, 2010.

[12] Z. Liu, S. W. Tay, and X. Li, 
"Rechargeable battery using a novel iron oxide nanorods anode and a nickel hydroxide cathode in an aqueous electrolyte," Chem. Commun., vol. 47, no. 46, pp. 12473-12475, 2011.

[13] K. C. Wanta, W. Astuti, I. Perdana, and H. T. B. M. Petrus, "Kinetic study in atmospheric pressure organic acid leaching: Shrinking core model versus lump model," Minerals, vol. 10, no. 7, pp. $1-10,2020$.

[14] A. K. Shukla, S. Venugopalan, and B. Hariprakash, "Nickel-based rechargeable batteries," J. Power Sources, vol. 100, no. 1-2, pp. 125-148, 2001.

[15] M. Geng, "Pasted Nickel Hydroxide Electrode and Additives for Rechargeable Alkaline Batteries," U.S. Patent 9,337,483 B2, May 10, 2016.

[16] W. K. Hu, X. P. Gao, D. Noréus, T. Burchardt, and N. K. Nakstad, "Evaluation of nano-crystal sized $\alpha$-nickel hydroxide as an electrode material for alkaline rechargeable cells," J. Power Sources, vol. 160, no. 1, pp. 704-710, 2006.

[17] J. Chen, D. H. Bradhurst, S. X. Dou, and H. K. Liu, "Nickel hydroxide as an active material for the positive electrode in rechargeable alkaline batteries," $J$. Electrochem. Soc., vol. 146, no. 10, pp. 3606-3612, 1999.

[18] D. D. Zhao, S. J. Bao, W. J. Zhou, and H. L. Li, "Preparation of hexagonal nanoporous nickel hydroxide film and its application for electrochemical capacitor," Electrochem. commun., vol. 9, no. 5, pp. 869-874, 2007.

[19] T. N. Ramesh and P. V. Kamath, "Synthesis of nickel hydroxide: Effect of precipitation conditions on phase selectivity and structural disorder," $J$. Power Sources, vol. 156, no. 2, pp. 655661, 2006.

[20] V. Asokbunyarat, P. N. L. Lens, and A. P. Annachhatre, Permeable Reactive Barriers for Heavy Metal Removal, vol. 1, pp. 101-120,2017.

[21] L. K. Wang, D. A. Vaccari, Y. Li, and N. K. Shammas, "Chemical Precipitation," Physicochem. Treat. Process., vol. 3, pp. 141-197, 2005.

[22] D. S. Hall, D. J. Lockwood, C. Bock, and B. R. MacDougall, "Nickel hydroxides and related materials: A review of their structures, synthesis and properties," Proc. R. Soc. A Math. Phys. Eng. Sci., vol. 471, no. 2174, 2015.

[23] K. C. Wanta, F. D. Putra, R. F. Susanti, G. P. Gemilar, W. Astuti, S. Virdhian, and H. T. B. M. Petrus, "Pengaruh derajat keasaman $(\mathrm{pH})$ dalam proses presipitasi hidroksida selektif ion logam dari larutan ekstrak spent catalyst," Jurnal Rekayasa Proses, 13(2), pp. 94-105, 2019.

[24] K. Ter Haar and W. Westerveld, "The colorimetric determination of nickel. As Ni4 dimethylglyoxime," Recl. des Trav. Chim. des Pays-Bas, vol. 67, no. 1, pp. 71-81, 1948.

[25] T. W. J. Albrecht, J. Addai-Mensah, and D. Fornasiero, "Effect of $\mathrm{pH}$, Concentration and Temperature on Copper and Zinc Hydroxide Formation / Precipitation in Solution," CHEMECA 2011 - "Engineering a Better World," pp. $1-10,2011$.

[26] H. Basturkcu and N. Acarkan, "Selective nickel-iron separation from atmospheric leach liquor of a lateritic nickel ore using the para-goethite method," Physicochem. Probl. Miner. Process., vol. 53, no. 1, pp. 212-226, 2017.

[27] M. M. Brbooti, B. Abid, and N. M. Alshuwaiki, "Removal of heavy metals Using chemicals precipitation," Enginering Technol. J., vol. 29, no. 3, pp. 595-612, 2011. 